\title{
THE ALVEOLAR CARBONIC ACID PRESSURE IN DISEASES OF THE BLOOD AND IN DISEASES OF THE RESPIRATORY AND CIRCULATORY SYSTEMS.1
}

\author{
By Mabel Purefoy FitzGerald.
}

From the Clinical Laboratory of the Radcliffe Infirmary, Oxford.

IT was shown by Haldane and Priestley $\left(1905^{1}\right)$ that under normal conditions respiration is so regulated as to maintain in each individual a practically constant alveolar carbonic acid pressure. Later, FitzGerald and Haldane $\left(1905^{2}\right.$ ), experimenting with a large number of normal individuals in a condition of rest, confirmed the individual constancy of the alveolar $\mathrm{CO}_{2}$ tension, and determined the limits of normal variation in men and women and boys and girls respectively.

The investigations forming the substance of the present paper were made for the purpose of determining the alveolar $\mathrm{CO}_{2}$ pressure, during rest, in conditions of disease. The experiments were carried out in the medical wards and in the out-patient department of the Radcliffe Infirmary, Oxford, and I take this opportunity of expressing my thanks to the physicians on both the senior and junior staffs for their courtesy in affording facilities for carrying out the research, and also to the sisters in charge as well as to the patients for their interested co-operation.

Over 400 experiments were made with patients suffering from diseases of the blood, respiratory, or circulatory systems. Many of the patients were under observation for several months. ${ }^{2}$

The method employed for determining the composition of the alveolar air was FitzGerald and Haldane's $\left(1905^{2}\right)$ modification of the Haldane and Priestley method, the small air analysis apparatus of Haldane being used for receiving the samples. This apparatus proved very adaptable to clinical use, and any difficulties arising either from weakness or other causes in conscious patients were readily overcome. The samples were generally taken both at the end of an inspiration and at the end of an expiration. In those cases in which difficulty was experienced in giving satisfactory " expiratory" samples only "inspiratory" samples were taken.

${ }^{1}$ Received September 30, 1909.

2 The main results were communicated to a meeting of the Pathological Society of Great Britain and Ireland in January 1908 ; but, owing to the writer's absence abroad, the publication of the paper has been delayed. 
As the $\mathrm{CO}_{2}$ percentage found by analysis was very similar in both types of samples, only the mean result of the day's experiments with each individual is given in the tables. These results represent, and are recorded, as percentages of $\mathrm{CO}_{2}$ in dry alveolar air. The actual partial pressure of $\mathrm{CO}_{2}$ in the alveolar air saturated at $37^{\circ} \mathrm{C}$. is expressed in millimetres of mercury, and is given in another column. This is calculated from the percentage of $\mathrm{CO}_{2}$ in the dry alveolar air as found by. analysis, and from the $8 \mathrm{a.m}$. reading of the barometric pressure recorded daily at the Radcliffe Observatory, adjacent to the Infirmary. In making the calculation the pressure of aqueous vapour in the saturated alveolar air was taken as $47 \mathrm{~mm}$. of mercury. Determinations of the amount of hæmoglobin present and of the number of red blood corpuscles were made in as many cases as possible. For these estimations a Gowers-Haldane hæmoglobinometer and a Thoma-Zeiss hæmocytometer were used. For making the blood counts two pipettes of blood were generally taken (dilution, 1-100), duplicate counts made, and the mean result recorded. If the results obtained from the two pipettes differed by more than 10 per cent. the counts were discarded.

\section{Alveolar Carbonic Acid Pressure in Diseases of the Blood.}

Of diseases of the blood the alveolar $\mathrm{CO}_{2}$ was examined in nineteen typical cases of chlorosis, in two cases of pernicious anæmia, one case of chronic polycythæmia with cyanosis and enlarged spleen (Vaquez and Osler's disease), and in two cases of secondary anæmia due to severe hæmorrhage. Over 200 experiments were performed.

Taking the average of the daily mean results (Tables II. and IV), the partial pressure of $\mathrm{CO}_{2}$ in each of these conditions is. seen to be within the normal limits of variation as previously determined $\left(1905^{2}\right)$, but the records also show that within these limits there is a general tendency in anæmic conditions towards a low pressure of $\mathrm{CO}_{2}$, since the average pressure is in each condition somewhat lower than the normal "mean" for men or women at ordinary atmospheric pressure.

Amongst the daily records, four examples occur which are below the minimum $\mathrm{CO}_{2}$ pressure recorded as normal. These will be referred to again in dealing with the individual cases to which they belong.

A tendency to irregularity in the alveolar $\mathrm{CO}_{2}$ pressure of the individual is also to be observed. In cases under observation for a long period a variation of from $1-3 \mathrm{~mm}$. of mercury was frequently noted, and this occurred, generally speaking, either as an oscillation or as a rise.

In two cases of chlorosis-Table I. (2) A. R. and (7) A. S.maximum variations of 6.8 (fall) and of $4 \mathrm{~mm}$. of mercury (rise) were respectively recorded (Table I.).

No constant parallelism could be traced between the alveolar $\mathrm{CO}_{2}$ pressure and either the percentage amount of hæmoglobin or the number of red-blood corpuscles present.

Owing to the similarity in the general results, brief mention only

22-JL. op PATH.-voz. XIv. 
is made of certain cases in each condition of disease investigated, together with a few general remarks.

\section{(A) Chlorosis.}

Taking the average of the mean results based on $1 \tilde{2} 2$ experiments, the partial pressure of $\mathrm{CO}_{2}$ found in chlorosis is slightly below the normal mean pressure for women (see Table II.); but no record of tension as low as the normal minimum pressure occur's.

The cases especially mentioned are selected from those who were under observation for several months, thus affording opportunity for the observation of any variation occurring during treatment and improvement in condition, and in relapse if such ensued.

CASE 13, A. W.-This patient had been under treatment, on and off, for four years, but had never entirely regained her health. When she was first seen the hæmoglobin was reduced to 29 per cent. and the red blood corpuscles to 80 per cent. of the normal. Breathlessness was very great on any exertion.

The partial pressure of $\mathrm{CO}_{2}$ was then $35.9 \mathrm{~mm}$. of mercury, or just below the normal mean for women.

Under treatment and on cessation of work improvement took place, the hæmoglobin rising to 73 per cent. The $\mathrm{CO}_{2}$ tension increased during this time to $38.4 \mathrm{~mm}$. $\mathrm{Hg}$, a value just above the normal mean.

After her return to work (domestic service) the hæmoglobin again began to fall, and breathlessness returned on exertion, but the alveolar $\mathrm{CO}_{2}$ pressure was maintained at $38.4 \mathrm{~mm}$. of mercury.

CASE 15, E. W. (Tables I. and II.).-This patient was under abservation for six months. On presenting herself for treatment she complained of feeling ill for five months prior to this, and was ultimately forced to abandon work. Breathlessness was very great. The $\mathrm{CO}_{2}$ pressure was found to be 32 $\mathrm{mm}$. of mercury, a value that is above the normal minimum pressure for women. The hæmoglobin at this time was reduced to 31 per cent. The $\mathrm{CO}_{2}$ pressure varied very little during the improvement in her condition.

In a relapse that followed three months later the hæmoglobin was reduced to 28 per cent., and the $\mathrm{CO}_{2}$ tension, whilst decreasing slightly, was still within normal limits. During the six months of observation the alveolar $\mathrm{CO}_{2}$ pressure showed a maximum variation of $2.4 \mathrm{~mm}$. of mercury.

Case 5, F. M. (Tables I. and II.).-This was another severe case. The $\mathrm{CO}_{2}$ pressure, although very low $(31.6 \mathrm{~mm}$. $\mathrm{Hg}$ ), was nevertheless maintained within normal limits, while the hæmoglobin was reduced to 27 per cent.

In CASE 9, E. H. (Tables I, and II.), the records show the same tension of $\mathrm{CO}_{2}$ in the alveolar air $(34 \mathrm{~mm} . \mathrm{Hg})$ with 25 per cent. of hæmoglobin as with 78 per cent.

Similar results were obtained in Case 1, E. T. (Tables I. and II.), whose alveolar $\mathrm{CO}_{2}$ pressure oscillated between 31.7 and $33.9 \mathrm{~mm}$. of mercury; the pressure being almost the same with 36 per cent. as with 74 per cent. of hæmoglobin.

CASE 14, A. C. (Tables I. and II.), was an instance of the maintenance of the $\mathrm{CO}_{2}$ pressure nearer the higher limit for normal (average $39 \cdot 6 \mathrm{~mm}$. $\mathrm{Hg}$ ), and on one occasion the records show a tension higher than normal maximum pressure for women. 
TABLE I.-Diseases of the Blood.

CHLOROSIS.

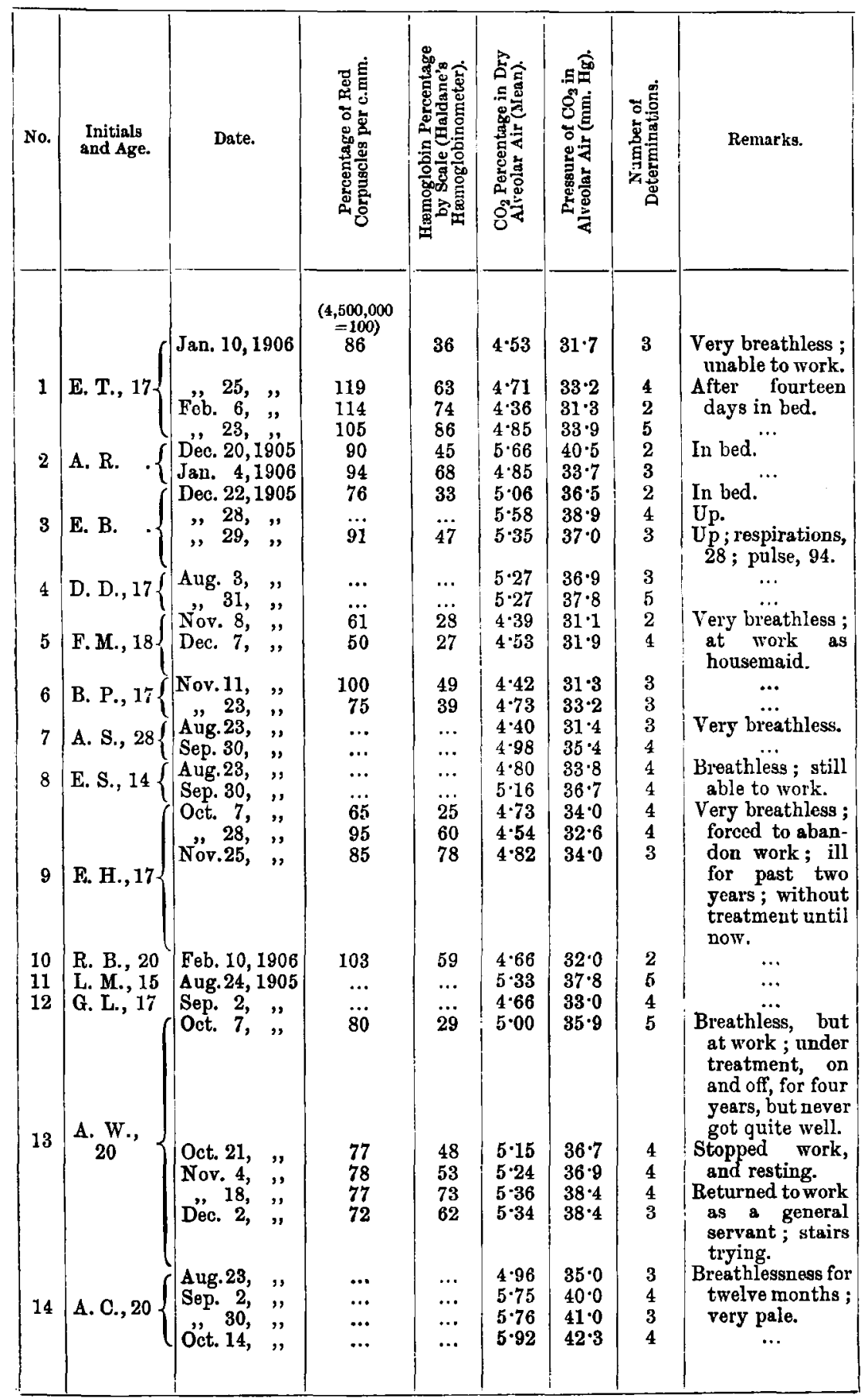


TABLE I.-Diseases of the Blood (continued).

\begin{tabular}{|c|c|c|c|c|c|c|c|c|}
\hline No. & $\begin{array}{c}\text { Initials } \\
\text { and Age. }\end{array}$ & Date. & 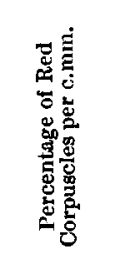 & 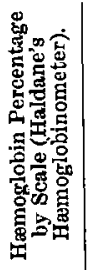 & 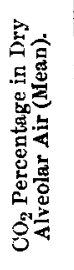 & 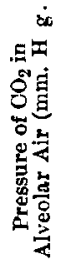 & 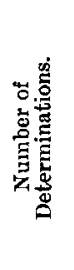 & Remarks. \\
\hline $\begin{array}{l}16 \\
17 \\
18 \\
19\end{array}$ & $\begin{array}{l}\text { E. N. } \\
\text { R. G., } 14 \\
\text { M. K., } 21 \\
\text { W. N., } 14\end{array}$ & 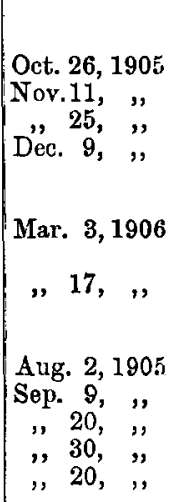 & $\begin{array}{c}(4,500,000 \\
=100 \\
71 \\
88 \\
108 \\
84 \\
\\
\\
60 \\
\\
\ldots \\
\\
\ldots \\
\ldots \\
\ldots \\
\ldots \\
\ldots\end{array}$ & $\begin{array}{l}31 \\
59 \\
63 \\
53 \\
\\
\\
28 \\
\ldots\end{array}$ & $\begin{array}{l}4 \cdot 45 \\
4 \cdot 61 \\
\ldots \cdot 62 \\
4 \cdot 62 \\
4 \cdot 38 \\
4 \cdot 34 \\
\\
\\
4 \cdot 55 \\
5 \cdot 12 \\
4 \cdot 53 \\
5 \cdot 01 \\
5 \cdot 10\end{array}$ & $\begin{array}{c}32 \cdot 0 \\
32 \cdot 0 \\
33 \cdot 1 \\
\\
\\
31 \cdot 6 \\
\\
30 \cdot 9 \\
\\
\\
\\
32 \cdot 3 \\
36 \cdot 2 \\
32 \cdot 3 \\
35 \cdot 6 \\
36 \cdot 6\end{array}$ & $\begin{array}{c}4 \\
4 \\
\dddot{5} \\
\\
4 \\
3\end{array}$ & $\begin{array}{l}\text { Anæmic for past } \\
\text { five months } \\
\text { obliged to aban- } \\
\text { don work as } \\
\text { domestic ser- } \\
\text { vant. } \\
\text { Relapse after re- } \\
\text { turn to work. } \\
\text { Breathlessness } \\
\text { extreme, and } \\
\text { faintncss. } \\
\ldots \\
\ldots \\
\ldots \\
\ldots \\
\ldots\end{array}$ \\
\hline
\end{tabular}

TaBLE II.-Diseases of the Blood. CHLOROSIS.

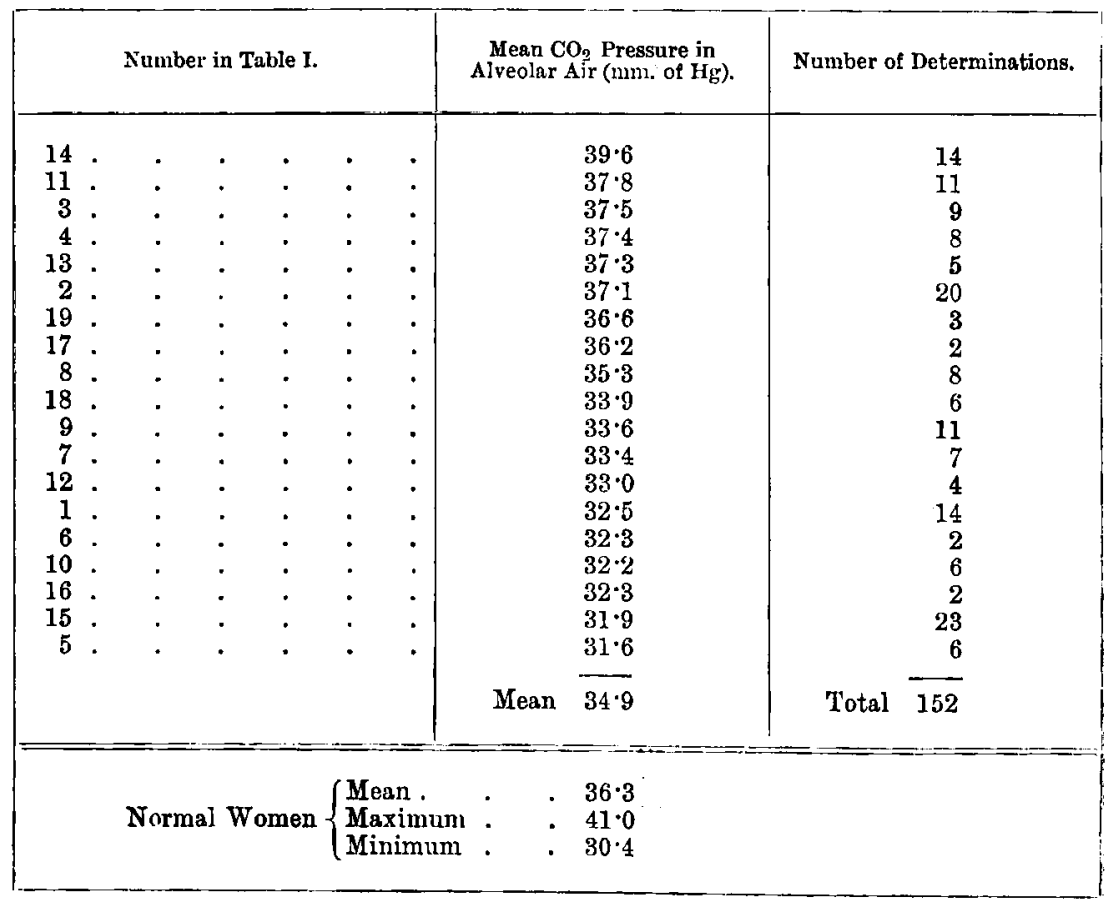




\section{(B) Pernicious Ancemia.}

CASE 20, F. S., male (Tables III. and IV.).-This was a very marked case of pernicious anæmia, and was under observation for two and a half months. This period embraced part of his second attack, and a brief spell of improvement prior to the onset of the third and fatal attack.

The partial pressure of $\mathrm{CO}_{2}$ oscillated between 31.3 and $33.9 \mathrm{~mm}$. of mercury, giving a mean of $32 \cdot 6$, a value corresponding to the minimum $\mathrm{CO}_{2}$ pressure recorded for normal men at ordinary atmospheric pressure.

TABLE III.-Diseases of the Blood.

PERNICIOUS ANEEMIA

(MEN).

\begin{tabular}{|c|c|c|c|c|c|c|c|c|}
\hline No. & $\begin{array}{l}\text { Initials and } \\
\text { Age. }\end{array}$ & Date. & 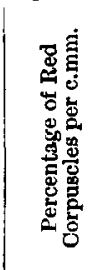 & 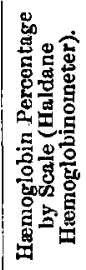 & 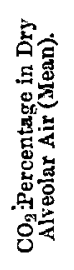 & 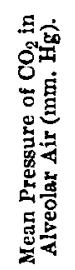 & 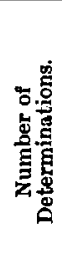 & Remarks. \\
\hline 20 & F. S., 45 & 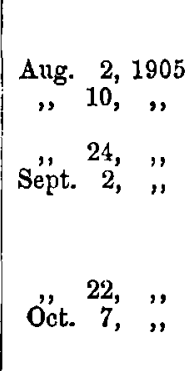 & $\begin{array}{c}(5,000,000 \\
=100) \\
\ldots \\
\cdots \\
34 \\
43 \\
\\
\\
29 \\
31\end{array}$ & $\begin{array}{l}\ldots \\
\cdots \\
42 \\
46\end{array}$ & $\begin{array}{l}4 \cdot 61 \\
4 \cdot 50 \\
4 \cdot 60 \\
4 \cdot 78 \\
\\
4 \cdot 70 \\
4 \cdot 36\end{array}$ & $\begin{array}{l}32 \cdot 7 \\
31 \cdot 9 \\
\\
32 \cdot 7 \\
33 \cdot 9 \\
\\
\\
\\
\\
33 \cdot 6 \\
31 \cdot 3\end{array}$ & $\begin{array}{l}2 \\
3 \\
4 \\
4 \\
\\
\\
5 \\
4\end{array}$ & $\begin{array}{l}\text { Verg weak ; } \\
\text { brought down } \\
\text { in chair. } \\
\text { Up; able to walk } \\
\text { about garden } \\
\text { and to go up- } \\
\text { stairs without } \\
\text { discomfort. } \\
\text { Walking about. } \\
\text { Died a few weeks } \\
\text { later. }\end{array}$ \\
\hline \multicolumn{9}{|c|}{$\begin{array}{l}\text { PERNICIOUS AN } \text { ASMIA } \\
\text { (WOMEN). }\end{array}$} \\
\hline 21 & F. M. , 44 & $\begin{array}{l}\text { Aug. } 8,1905 \\
\text { ", 14, ", } \\
\text { 23, ", } \\
\text { Sept. 9, ", } \\
\text { Oct. 14, ", } \\
\text { Nov. 11, " } \\
\text { Dec. 9, ", }\end{array}$ & $\left(\begin{array}{c}(4,500,000 \\
=100) \\
\cdots \\
\\
66 \\
65\end{array}\right.$ & $\begin{array}{l}75 \\
\ldots \\
\ldots \\
82 \\
83\end{array}$ & $\begin{array}{l}4 \cdot 81 \\
4 \cdot 60 \\
4 \cdot 99 \\
4 \cdot 99 \\
4 \cdot 70\end{array}$ & $\begin{array}{c}36 \cdot 0 \\
\\
33 \cdot 1 \\
\ldots \\
\\
\\
34 \cdot 0 \\
33 \cdot 0 \\
35 \cdot 7 \\
34 \cdot 0 \\
33 \cdot 7\end{array}$ & $\begin{array}{l}3 \\
\cdots \\
\\
\\
3 \\
4 \\
3 \\
4 \\
5\end{array}$ & $\begin{array}{l}\text { Has been very } \\
\text { short of breath; } \\
\text { patient in bed. } \\
\text { Up; able to walk } \\
\text { about garden } \\
\text { and to go up- } \\
\text { stairs. } \\
\text { At work. } \\
\ldots \\
\ldots \\
\ldots \\
\text { Died a few weeks } \\
\text { later. }\end{array}$ \\
\hline
\end{tabular}


TABle III.-Diseases of the Blood (continued). SECONDARY ANAEMIA

(WoMLN).

\begin{tabular}{|c|c|c|c|c|c|c|c|c|}
\hline No. & $\begin{array}{l}\text { Initials and } \\
\text { Age. }\end{array}$ & Date. & 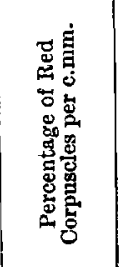 & 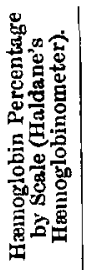 & 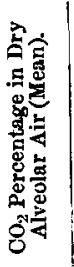 & 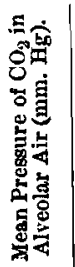 & 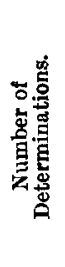 & Remarks. \\
\hline 22 & M. S., 34 & 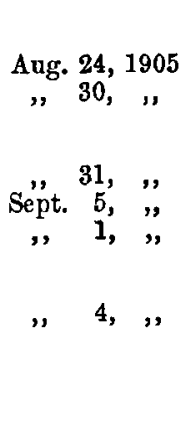 & $\begin{array}{c}(4,500,000 \\
=100) \\
45 \\
\ldots \\
\\
\ldots \\
\cdots \\
\\
\ldots\end{array}$ & $\begin{array}{l}52 \\
\cdots \\
\ldots\end{array}$ & $\begin{array}{c}4 \cdot 19 \\
4 \cdot 69 \\
\\
4.56 \\
\ldots .03 \\
\\
5.33\end{array}$ & $\begin{array}{l}29 \cdot 8 \\
33 \cdot 0 \\
\\
32 \cdot 7 \\
\dddot{36 \cdot 1} \\
\\
38 \cdot 1\end{array}$ & $\begin{array}{c}3 \\
\dddot{2} \\
1\end{array}$ & $\begin{array}{l}\text { Placenta prævia; } \\
\text { severe hæmor- } \\
\text { r h a g e ; very } \\
\text { weak ; in bed. } \\
\text { Able to get up. } \\
\text { (Deaf and Dumb) } \\
\text { Hæm a temesis } \\
\text { (gastric ulcer). } \\
\text { Very pale; lips } \\
\text { quite white ; } \\
\text { unable to sit } \\
\text { up in bed. }\end{array}$ \\
\hline \multicolumn{9}{|c|}{ SPLENOMEGALY WITH } \\
\hline 24 & E. H., 45\{ & $\begin{array}{c}\text { Dec. 4, } 1907 \\
=11, \quad "\end{array}$ & $\begin{array}{c}(4,500,000 \\
=100) \\
175 \\
145\end{array}$ & $\begin{array}{l}148 \\
161\end{array}$ & $\begin{array}{l}4 \cdot 13 \\
4 \cdot 61\end{array}$ & $\begin{array}{l}28 \cdot 7 \\
32 \cdot 1\end{array}$ & $\begin{array}{l}3 \\
4\end{array}$ & $\begin{array}{c}\text { In bed. } \\
\quad "\end{array}$ \\
\hline
\end{tabular}

TABLE IV.-Diseases of the Blood (continued).

\begin{tabular}{|c|c|c|c|}
\hline & Number in Table III. & $\begin{array}{l}\text { Mean Pressure of } \\
\mathrm{CO}_{2} \text { in Alveolar Air } \\
\text { (mm. of } \mathrm{Hg}) .\end{array}$ & $\begin{array}{c}\text { Number of } \\
\text { Determinations. }\end{array}$ \\
\hline $\begin{array}{l}\text { Pernicious anæmia (man) } \\
\text { Secondary anæmia (woman) } \\
\begin{array}{l}\text { Polycythremia with cyanosis and } \\
\text { enlarged spleen }\end{array} \\
\text { Normal men } \cdot\left\{\begin{array}{l}\text { Maximum } \\
\text { Minimum } \\
\text { Mean }:\end{array}\right. \\
\text { Normal women } \\
\begin{array}{l}\text { Maximum } \\
\text { Minimum } \\
\text { Mean }:\end{array}\end{array}$ & $\begin{array}{l}20 \\
21 \\
23 \\
22 \\
24 \\
\cdots \\
\cdots \\
\cdots \\
\cdots \\
\cdots \\
\cdots\end{array}$ & $\begin{array}{l}32 \cdot 6 \\
34 \cdot 2 \\
37 \cdot 1 \\
31 \cdot 8 \\
30 \cdot 4 \\
44 \cdot 5 \\
32 \cdot 6 \\
39 \cdot 2 \\
41 \cdot 0 \\
30 \cdot 4 \\
36 \cdot 3\end{array}$ & $\begin{array}{r}22 \\
24 \\
3 \\
6 \\
7 \\
\cdots \\
\cdots \\
\cdots \\
\cdots \\
\cdots \\
\cdots\end{array}$ \\
\hline
\end{tabular}


On two occasions the $\mathrm{CO}_{2}$ pressure was below the minimum normal for men, and equivalent to 31.3 and $31.9 \mathrm{~mm}$. of mercury respectively.

When the first samples of alveolar air were taken, the patient was very weak, - barely able to sit up, and complained much of shortness of breath. At this time the $\mathrm{CO}_{2}$ partial pressure was $32.6 \mathrm{~mm}$. of mercury, the normal minimum pressure. The same tension was recorded three weeks later, when the patient was able to walk about the hospital grounds and upstairs without discomfort or shortriess of breath.

The hæmoglobin was reduced to less than half the normal amount, and the red blood corpuscles to less than one-third normal; the hæmoglobin varying between 42 and 46 per cent., and the red corpuscles between 29 and 43 per cent. of the normal.

The higher pressures of $\mathrm{CO}_{2}$ recorded $(33.6$ and $33.9 \mathrm{~mm} . \mathrm{Hg})$ were in this case associated with the higher percentage values of hæmoglobin.

CaSe 21, F. M., female (Tables III. and IV.).-During the five months this patient was under observation, both as an in-patient in a serious condition and as an out-patient able to work, the alveolar $\mathrm{CO}_{2}$ pressure varied between the normal minimum and the normal mean pressure for women (mean 34.2 mm. $\mathrm{Hg}$ ). Shortness of breath was a marked feature at different times.

\section{(C) Chronic Polycythomia and Cyanosis with Enlarged Spleen.}

Case 24, E. H., female (Tables III. and IV.).--In this very interesting case of Vacquez and Osler's disease the average alveolar $\mathrm{CO}_{2}$ pressure was found to be the same as the minimum normal pressure for women.

One record, however, shows a tension still lower $(28.7 \mathrm{~mm}$. $\mathrm{Hg})$. Breathlessness had not been a marked symptom.

It must also be observed that very high percentages of hæmoglobin, and red corpuseles numbering between 6 and 7 millions to the cubic millimetre, are here associated with an alveolar $\mathrm{CO}_{2}$ tension corresponding to the minimum normal.

\section{(D) Secondary Ancemia.}

At the time of obtaining the earlier samples of alveolar air, extreme weakness and pallor marked the condition of both patients suffering from secondary anæmia, ascribable in the one case (22), M. S., to severe postpartum hæmorrhage and in the other (23), K. T., to hæmorrhage from a gastric ulcer.

With K. T., 23 (gastric ulcer) (Tables III. and IV.), the $\mathrm{CO}_{2}$ pressure was the same as the normal mean for women, and later increased $2 \mathrm{~mm}$. of mercury.

In the case of M. S., 22, placenta prævia (Tables III. and IV.), the $\mathrm{CO}_{2}$ pressure kept very near the normal minimum pressure of $30.6 \mathrm{~mm}$. of mercury, the first samples recording a tension $0.6 \mathrm{~mm}$. below this.

The hæmoglobin at the same time was reduced to less than one-fourth of the normal and the red corpuscles to less than one-half of the normal.

Since the alveolar $\mathrm{CO}_{2}$ is maintained at nearly normal pressure in chlorosis and in other anæmic conditions, and since even a slight deficiency in the oxygen supply to the tissues would lower the alveolar $\mathrm{CO}_{2}{ }^{1}$ it appears evident that a compensatory process, almost com-

1 See the papers of Boycott and Haldane, of Ward, and of Haldane and Poulton, Journ. Physiol., 1908, Cambridge and London, vol. xxxviii. py. 355, 378, and 390 ; also Haldane, Brit. Med. Journ., 1908, vol. ii. p. 578. 
pletely effective during rest, is brought into play; and this can only be an increased rate of blood flow. With the oxygen-carrying power of the blood reduced to one-third or less of the normal, as has been frequently observed in the cases above mentioned, ${ }^{1}$ marked symptoms of want of oxygen would appear (as is actually the case in CO-poisoning, as shown by Haldane) even in rest, unless the circulation was increased. The fact that compensation occurs in this way, the heart being unable at times (as during muscular exertions) to respond fully, will therefore account for many of the circulatory and respiratory symptoms met with in anremia.

\section{Alveolar Carbonic Acid, Pressurt in Disease of tire Respiratory SYS'TEM.}

Fourteen patients were examined suffering from diseases of the respiratory system, which included preumonia, early and advanced phthisis, tuberculous pleurisy and empyema, asthma, emphysema, and one case of hysterical dyspncea.

Ninety-one experiments were performed.

With but three exceptions in the mean records, to be referred to later, the partial pressure of $\mathrm{CO}_{2}$ in the alveolar air was maintained within the normal limits. Generally speaking, the tension was found to vary between the normal minimum and the normal mean pressure for men, women, boys, or girls respectively.

Low tensions, i.e. near the normal minimum, were found in advanced cases of phthisis; tensions near the normal mean in early cases of the same disease, and in tuberculous pleurisy and empyema.

To take a special case, R. G. (31, Tables V. and VI.) was suffering from an empyema that had persisted for some time. The left lung was in a condition of partial collapse and very little air was entering on this side; the chest wall was markedly deformed. The $\mathrm{CO}_{2}$ tension was, however, maintained at the normal mean for boys $(37.2 \mathrm{~mm}$.).

A partial pressure of $\mathrm{CO}_{2}$ lower than the minimum normal for men was found with D. K. (26, Tables V. and VI.), the severest of the four cases of pneumonia investigated. The first samples were taken six days after the crisis, but at a time when the patient was still very ill and weak. The tension of $\mathrm{CO}_{2}$ was then only $\mathbf{2 6 . 3} \mathrm{mm}$. of mercury, the temperature of the body 97, and respiration 25. As improvement took place the $\mathrm{CO}_{2}$ pressure rose, at first to the minimum pressure for men, and fifteen days later to just below the normal mean for men. The increase in tension recorded was $8 \mathrm{~mm}$. of mercury.

Arrother instance of the $\mathrm{CO}_{2}$ pressure being on two occasions outside the normal limits is found in the case of A. C. (35, Tables V. and VI.), a nervous woman suffering from bronchitis and asthma.

\footnotetext{
1 That the oxygen carrying power of the hæmoglobin in anæmia and other pathological conditions is accurately indicated by the Gowers-Haldane hamoglobinometer, has recently been experimentally proved by Morawitz and Röhmer, Arch. f. klin. Hed., 1908, Bd. xciv. S. 540 .
} 
A mean $\mathrm{CO}_{2}$ pressure of $25 \mathrm{~mm}$. of mercury was recorded at a time when the breathing was very distressed. The pulse was 116 (usually 96), and respirations 24 .

With this subject the alveolar $\mathrm{CO}_{2}$ tension was very variable, the samples on each day were consistent, but from the records it will be seen that there is a maximum difference of over $8 \mathrm{~mm}$. The total mean of $29.6 \mathrm{~mm}$. of mercury is just below the value for the minimum pressure in women.

The fact that in most of the cases investigated the alveolar $\mathrm{CO}_{2}$ pressure was about normal indicates that almost all the blood passing through the lungs was normally arterialised. Had any considerable

TABLE V.-Diseases of the Respiratory System.

Mex.

\begin{tabular}{|c|c|c|c|c|c|c|c|c|c|}
\hline No. & $\begin{array}{c}\text { Initials } \\
\text { and Age. }\end{array}$ & Disease. & Date. & 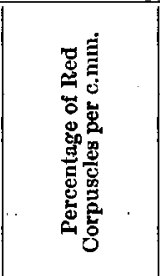 & 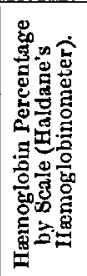 & 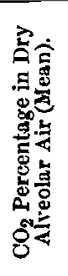 & 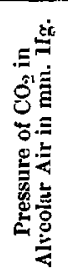 & 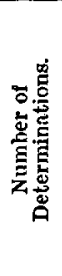 & Remarks. \\
\hline $\begin{array}{l}27 \\
28 \\
29 \\
30\end{array}$ & $\begin{array}{l}\left\{\begin{array}{c}\text { W. H., } \\
16 \\
\text { E.J.W., } \\
27\end{array}\right. \\
\text { R. s., } 29 \\
\text { C. B., } 68\end{array}$ & $\begin{array}{c}\text { Pneumonia } \\
\text { (left side) } \\
\\
\text { Pneumonia } \\
\text { (right side) } \\
\\
\text { Pneumonia } \\
\text { (bothlungs) } \\
\text { Advanced } \\
\text { phthisis, } \\
\text { Dyspnea } \\
\text { (hysterical) } \\
\text { Empyenia }\end{array}$ & 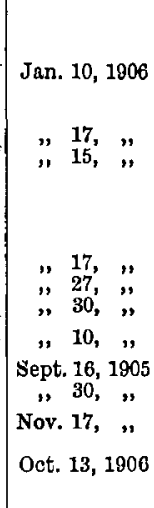 & $\begin{array}{c}(5,000,000,000 \\
=100) \\
. \\
\ddot{6 g}\end{array}$ & $\begin{array}{c}. . \\
. \\
98 \\
64 \\
\ddot{1} \\
105 \\
. .\end{array}$ & $\begin{array}{l}5 \cdot 37 \\
\\
5 \cdot 50 \\
3 \cdot 72 \\
\\
4 \cdot 11 \\
4 \cdot 27 \\
4 \cdot 78 \\
6 \cdot 01 \\
4.60 \\
4 \cdot 68 \\
5 \cdot 52\end{array}$ & $\begin{array}{l}37 \cdot 5 \\
38 \cdot 9 \\
36 \cdot 3 \\
\\
29 \cdot 1 \\
30 \cdot 5 \\
34 \cdot 4 \\
41 \cdot 9 \\
3 \ddot{z} \cdot 7 \\
33 \cdot 5 \\
39 \cdot 2\end{array}$ & $\begin{array}{l}4 \\
2 \\
4 \\
5 \\
\dddot{5} \\
0 \\
6 \\
3\end{array}$ & 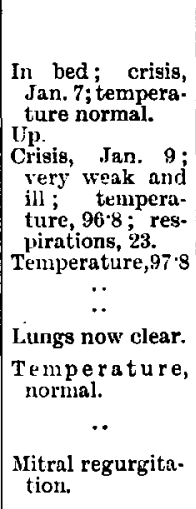 \\
\hline \multicolumn{10}{|c|}{ Boys. } \\
\hline 32 & R. G., 12 & $\left.\begin{array}{c}\text { Tubercular } \\
\text { pleurisy } \\
\text { (right side) }\end{array}\right\}$ & 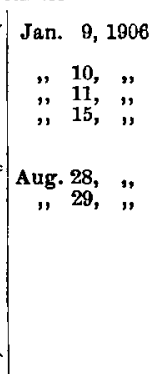 & .. & $\begin{array}{l}8 \dot{85} \\
89 \\
. .\end{array}$ & $\begin{array}{l}5 \cdot 34 \\
5 \cdot 34 \\
0 \cdot 26 \\
\\
5 \cdot 19 \\
5 \cdot 21\end{array}$ & $\begin{array}{l}37 \cdot 2 \\
3 \div \cdot 3 \\
3 \div \cdot 2 \\
\\
36 \cdot 1 \\
36 \cdot 2\end{array}$ & $\begin{array}{l}3 \\
3 \\
\ddot{2} \\
2 \\
4\end{array}$ & 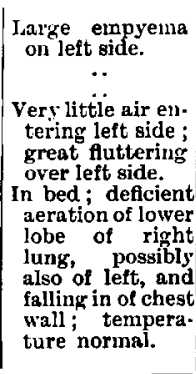 \\
\hline
\end{tabular}


TABLE V.-Diseases of the Respiratory System (continued).

WOMEN.

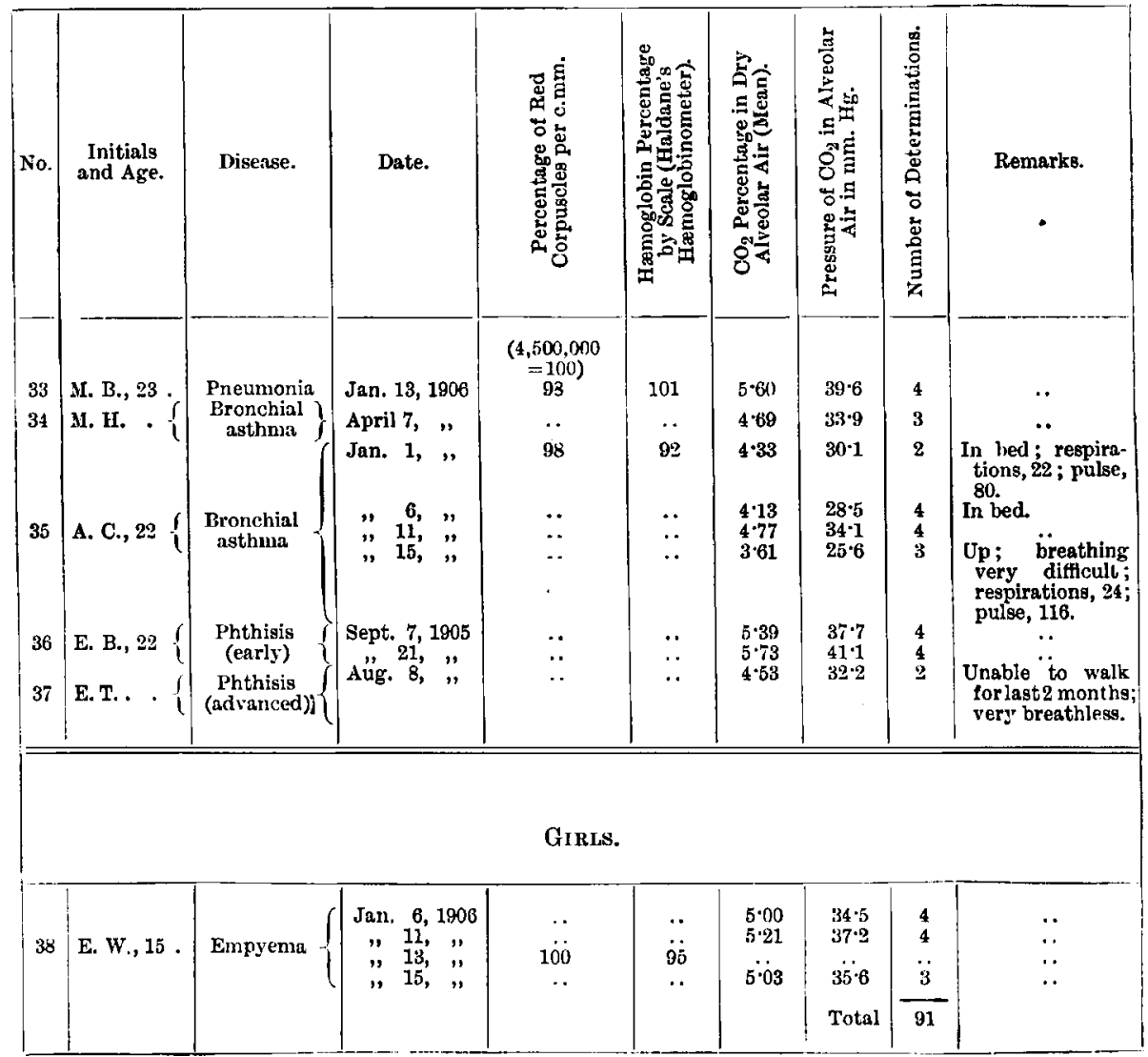

TABLE VI.-Diseases of the Respiratory Sygtem.

MEN.

\begin{tabular}{|c|c|c|c|}
\hline & $\begin{array}{l}\text { Number as in } \\
\text { Table V. }\end{array}$ & $\begin{array}{l}\text { Mean } \mathrm{CO}_{2} \text { l'ressure } \\
\text { in Alveolar Air. }\end{array}$ & $\begin{array}{l}\text { Total Number of } \\
\text { Determinations. }\end{array}$ \\
\hline \multirow[t]{2}{*}{ 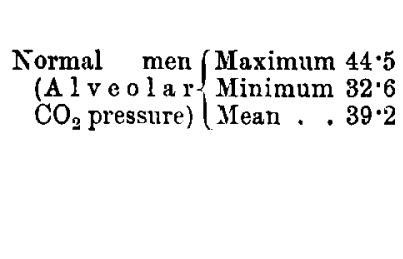 } & $\left\{\begin{array}{l}27 \\
30 \\
25 \\
29 \\
28 \\
26\end{array}\right.$ & $\begin{array}{l}41 \cdot 9 \\
39 \cdot 2 \\
38 \cdot 2 \\
33 \cdot 3 \\
32 \cdot 7 \\
29 \cdot 8\end{array}$ & $\begin{array}{r}5 \\
3 \\
7 \\
6 \\
2 \\
15\end{array}$ \\
\hline & & Mean $35 \cdot 8$ & Total 38 \\
\hline
\end{tabular}


TABLE VI.-Diseases of the Respiratory System (continued).

Bors.

\begin{tabular}{|c|c|c|c|c|}
\hline & & $\begin{array}{l}\text { Number as in } \\
\text { Table v. }\end{array}$ & $\begin{array}{l}\text { Mean } \mathrm{CO}_{2} \text { Pressure } \\
\text { in Alveolar Air. }\end{array}$ & $\begin{array}{l}\text { Total Number } \\
\text { of Determinations. }\end{array}$ \\
\hline \multirow[t]{2}{*}{ Normal boys } & \multirow[t]{2}{*}{$\begin{array}{l}\text { Maximum } 42 \cdot 1 \\
\text { Mininıum } 30 \cdot 6 \\
\text { Mean } . .37 \cdot 2\end{array}$} & $\begin{array}{l}31 \\
72\end{array}$ & $\begin{array}{l}37 \cdot 2 \\
36 \cdot 2\end{array}$ & $\begin{array}{l}8 \\
6\end{array}$ \\
\hline & & & Mean $36 \cdot 7$ & Total 16 \\
\hline \multicolumn{5}{|c|}{ WOMEN. } \\
\hline \multirow[t]{2}{*}{ Normal women } & \multirow[t]{2}{*}{$\begin{array}{l}\text { Maximum } 41 \cdot 0 \\
\text { Minimum } 30^{\circ} 4 \\
\text { Mean. } .36 \cdot 3\end{array}$} & $\left\{\begin{array}{l}33 \\
36 \\
34 \\
37 \\
35\end{array}\right.$ & $\begin{array}{l}39 \cdot 6 \\
39 \cdot 4 \\
33 \cdot 9 \\
32 \cdot 2 \\
29 \cdot 6\end{array}$ & $\begin{array}{r}4 \\
8 \\
3 \\
2 \\
11\end{array}$ \\
\hline & & & Mean $34 \cdot 9$ & Total 28 \\
\hline \multicolumn{5}{|c|}{ GinLs. } \\
\hline Normal girls & $\left\{\begin{array}{l}\text { Maximum 40.1 } \\
\text { Minimum 31·2 } \\
\text { Mean . . 35.2 }\end{array}\right.$ & 38 & $35 \cdot 8$ & 11 \\
\hline
\end{tabular}

amount of blood passed through the blocked portions of lung, and thus escaped arterialisation, the breathing would certainly have been increased, with consequent fall in the alveolar $\mathrm{CO}_{2}$ pressure. The circulation is thus concentrated in the sound portions of the lung, and must be normal in amount.

\section{Alveolar Carbonic Acid Pressure in Diseases of the Circulatory System.}

In general, the alveolar $\mathrm{CO}_{2}$ pressure in men, women, or children suffering from diseases of the circulatory system is maintained within normal limits. The average tension is somewhat low, the total mean for each class as seen in Table VIII. being below the normal mean pressure in the same. One hundred and forty-one experiments were performed. A greater variation in the alveolar $\mathrm{CO}_{2}$ pressure pertaining to each individual was met with in this class of patients than in those previously mentioned, with a maximum variation of $8 \mathrm{~mm}$. of mercury. A fall in pressure of $7 \mathrm{~mm}$. of mercury occurred in two 
cases of mitral incompetency (V.S., 39, and F.L., 40) as the condition improved. In the latter case the $\mathrm{CO}_{2}$ tension decreased as the hæmoglobin and red corpuscles increased.

On the other hand, with J. E. (No. 42), an old man, the tension increased $6 \mathrm{~mm}$. of mercury. Oscillations in tension were observed in other cases.

Departure from the normal was observed in onc case of mitral stenosis, one case of mitral incompetency, and to a very maiked degree in congenital heart disease (pulmonary stenosis). Taking these in order :-

1. Mitral Stenosis (E. B., 47, Tables VII. and VIII.). The partial pressure of $\mathrm{CO}_{2}$ in this case, a young woman, was invariably below the minimum pressure for normal women, and varied from 27 to $29 \mathrm{~mm}$. of mercury. When first seen she was unable to work. Cyanosis and breathlessness were marked features.

2. Mitral incompetency. $\mathrm{CO}_{2}$ tensions above the normal maximum record for any class of subjects were found in the case of E. C. (44, Tables VII. and VIII.), an elderly woman suffering from mitral obstruction and incompetency with failing compensation, together with asthma. Cyanosis of the cheeks and lips was very marked and dyspnœa present. Possibly her respiratory centre was failing. From the analyses of the alveolar air obtained soon after

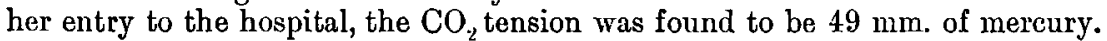
At that time she was in bed, and the respiration was very distressed. Twelve days later, when up, much relieved and cyanosis less evident, the partial pressure of $\mathrm{CO}_{2}$ had fallen to $45 \cdot 7 \mathrm{~mm}$. of mercury.

Taking even the mean of these values, $47 \cdot 4 \mathrm{~mm}$, the tension is considerably higher than the maximum recorded for normal men or women at ordinary atmospheric pressure.

3. Congenial heart disease, - A very interesting departure from the normal was observed in the case of L. M. (50, Tables VII. and VIII.). This case was one of a girl of 16 afflicted with pulmonary stenosis. Cyanosis was very marked and dyspnoen often great. During the six months that she was under observation, samples of the alveolar air were obtained under varied conditions, such as when keeping her bed, when up but barely able to walk about, and also at times when walking upstairs slowly could be accomplished without shortness of breath.

The partial pressure of $\mathrm{CO}_{2}$ varied from 21 to $25.3 \mathrm{~mm}$. of mercury, the percentage of $\mathrm{CO}_{2}$ from 2.98 to 3.59 , the maximum pressure and percentage being recorded at a time when breathlessness was again becoming more manifest.

When she was feeling at her best the $\mathrm{CO}_{2}$ pressure was $22 \cdot \overline{\mathrm{j} m}$. of mercury, the percentage of $\mathrm{CO}_{2} 3 \cdot 18$. The tensions here recorded are markedly lower than any observed under normal conditions. The hæmoglobin varied in amount from 157 to 165 per cent., and the red corpuscles from 158 to 184 per cent. of the normal.

In this case, and in No. 1 , it would seem that the circulatory defect was not compensated even during rest, and that as a consequence the respiratory centre was abnormally active. In the other cases the circulatory compensation was apparently almost complete 
TABLE VII.-Diseases of Circulatory System.

Mex.

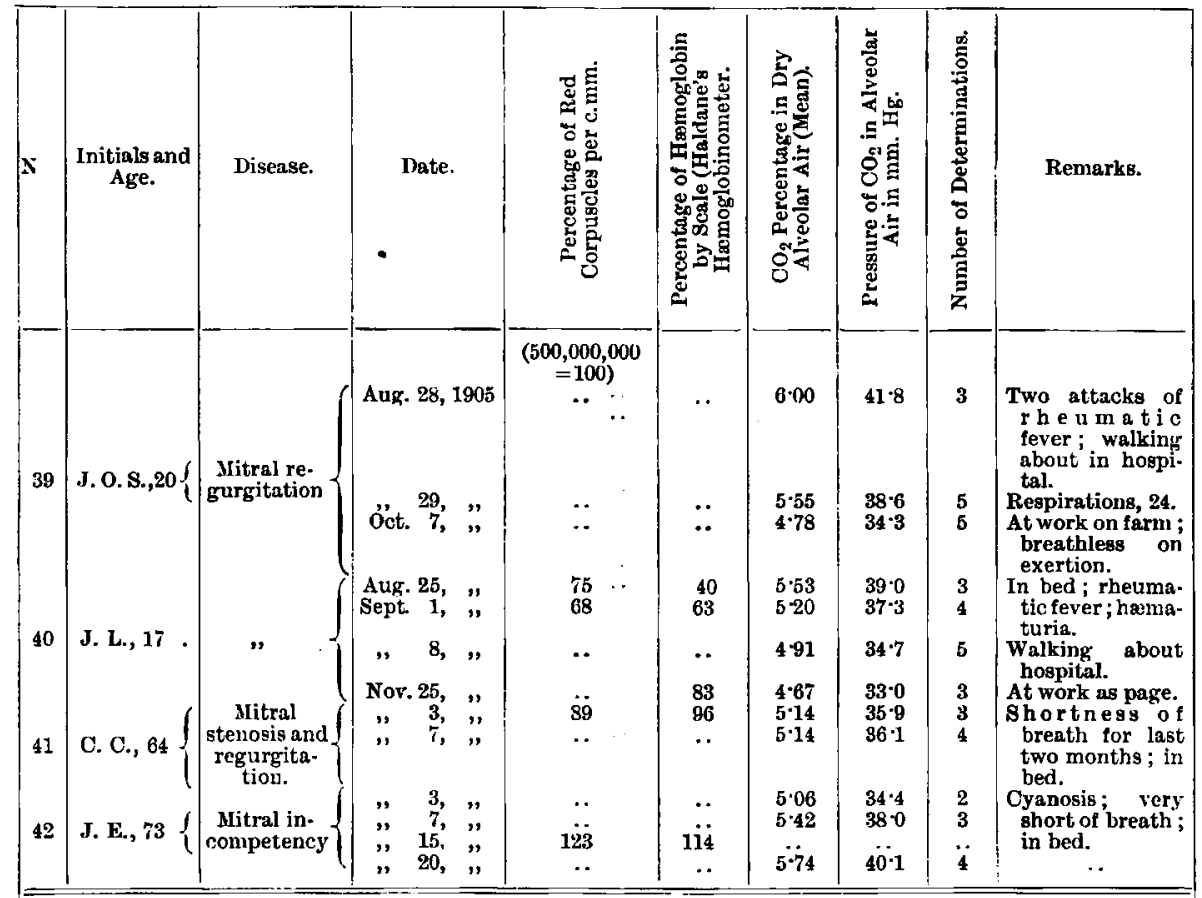

Boys.

\begin{tabular}{|c|c|c|c|c|c|c|c|c|c|c|}
\hline 43 & W. B., 12 & $\begin{array}{c}\text { Mitral in- } \\
\text { competency. }\end{array}$ & $\begin{array}{c}\text { Jan. } 17,19 \\
" 20, \\
" 125, \\
" 129,\end{array}$ & $\begin{array}{l}906 \\
" 1 \\
" 1\end{array}$ & $\begin{array}{l}\ddot{.} \\
\ddot{.}\end{array}$ & $\begin{array}{l}\ddot{*} \\
\ddot{9}\end{array}$ & $\begin{array}{l}4 \cdot 37 \\
5 \cdot 28 \\
4 \cdot 60 \\
4 \cdot 99\end{array}$ & $\begin{array}{l}30-1 \\
38-3 \\
32-4 \\
35 \cdot 6\end{array}$ & 4 & $\begin{array}{c}\text { In bed. } \\
\ldots \\
\ldots \\
\ldots\end{array}$ \\
\hline
\end{tabular}

WoMen.

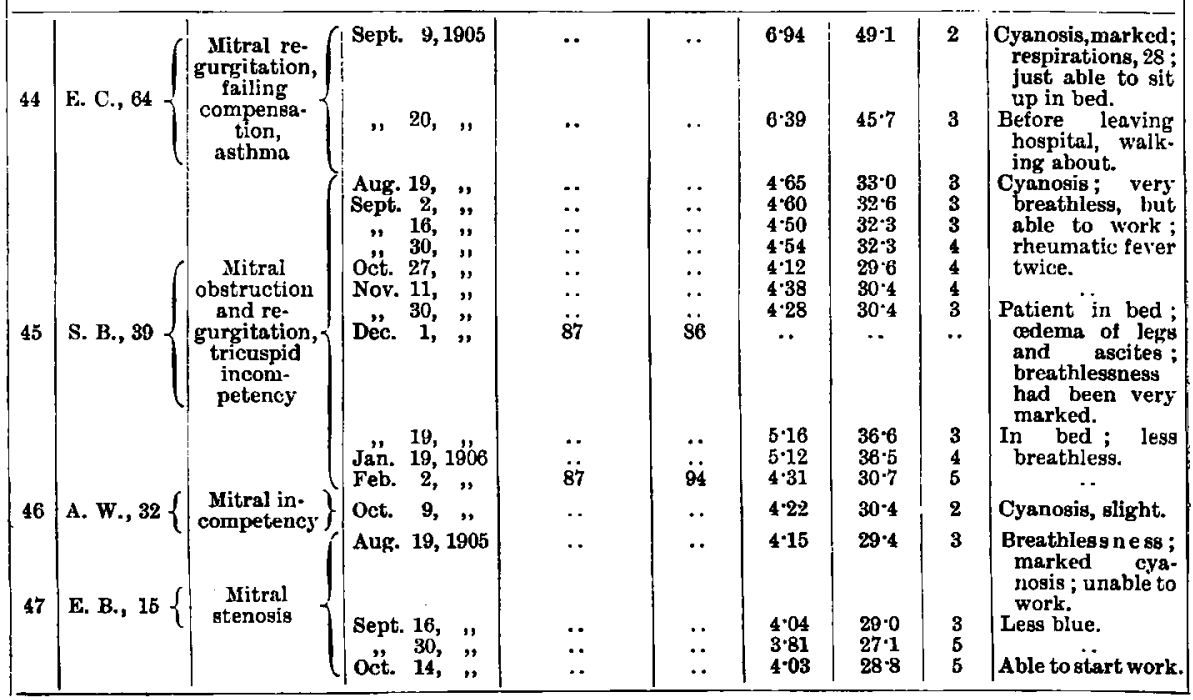


Table VII.-Diseases of Circulatory System (continued). Womkn (continued)

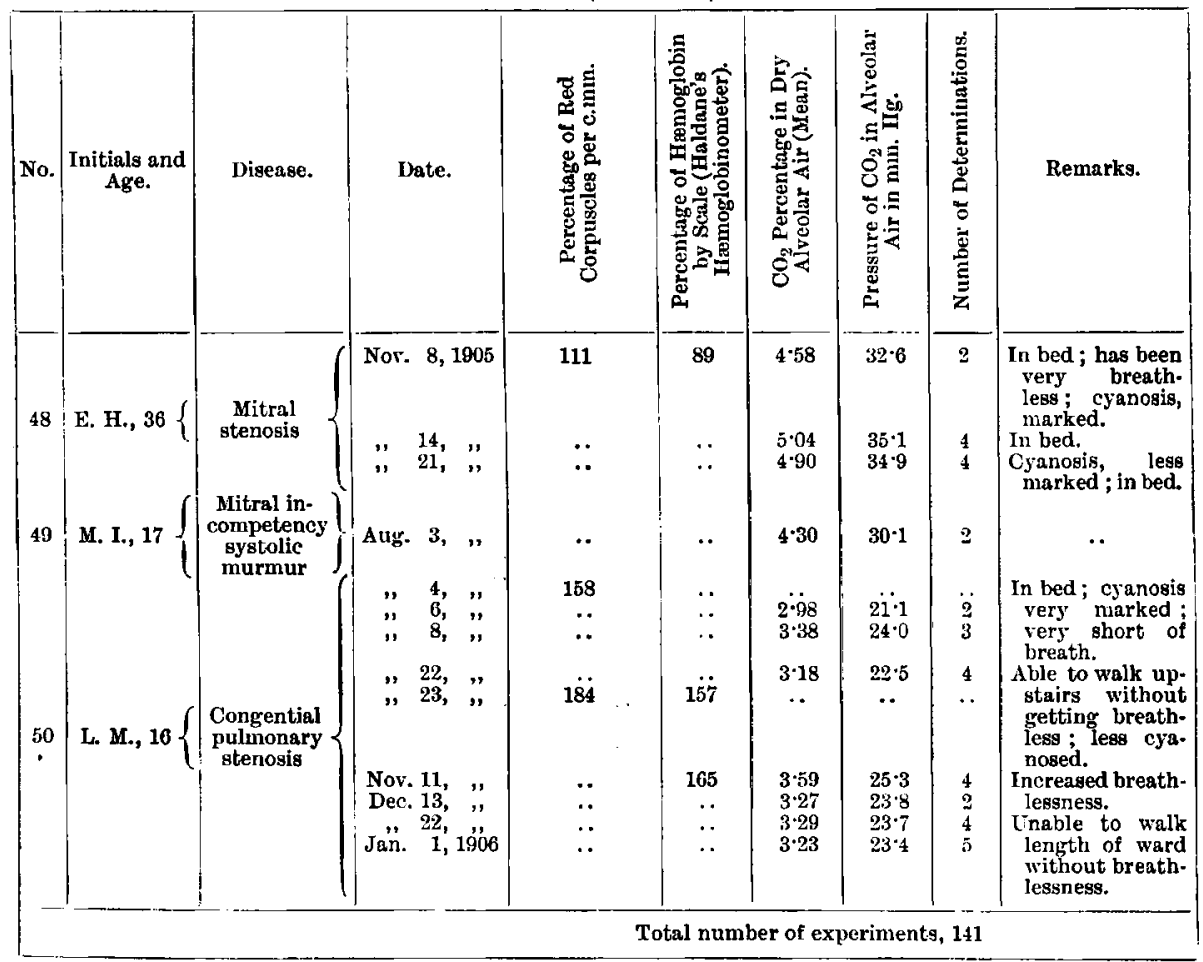

TABLE VIII. - Diseases of the Circuiatory System.

MEN.

\begin{tabular}{|c|c|c|c|}
\hline & $\begin{array}{l}\text { Number as in } \\
\text { Table VII. }\end{array}$ & $\begin{array}{l}\text { Mean } \mathrm{CO}_{2} \text { Pressure } \\
\text { in Alveolar Air. } \\
\text { In mm. Hg. }\end{array}$ & $\begin{array}{l}\text { Total Number of } \\
\text { Determinations. }\end{array}$ \\
\hline \multirow[t]{2}{*}{ 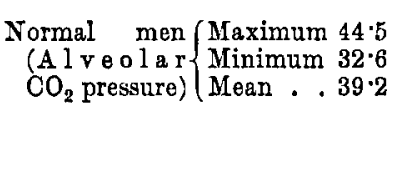 } & $\left\{\begin{array}{l}39 \\
42 \\
41 \\
40\end{array}\right.$ & $\begin{array}{l}38 \cdot 2 \\
37 \cdot 5 \\
36 \cdot 0 \\
36 \cdot 0\end{array}$ & $\begin{array}{r}13 \\
9 \\
7 \\
15\end{array}$ \\
\hline & & Mean $36 \cdot 9$ & Total 44 \\
\hline \multicolumn{4}{|c|}{ Boys. } \\
\hline Normal boys $\left\{\begin{array}{l}\text { Maximum } 42 \cdot 1 \\
\text { Minimum 30.6 } \\
\text { Mean . . 37.2 }\end{array}\right.$ & 43 & $33 \cdot 6$ & 12 \\
\hline \multicolumn{4}{|c|}{ WoMEN. } \\
\hline \multirow[t]{2}{*}{ Normal wornen $\left\{\begin{array}{l}\text { Maximum } 41 \cdot 0 \\
\text { Minimum } 30 \cdot 4 \\
\text { Mean } . .36 \cdot 3\end{array}\right.$} & $\left\{\begin{array}{l}44 \\
48 \\
45 \\
46 \\
49 \\
47 \\
50\end{array}\right.$ & $\begin{array}{l}47 \cdot 4 \\
35 \cdot 5 \\
32 \cdot 4 \\
30 \cdot 4 \\
30 \cdot 1 \\
28 \cdot 5 \\
23 \cdot 4\end{array}$ & $\begin{array}{r}5 \\
10 \\
36 \\
2 \\
2 \\
16 \\
24\end{array}$ \\
\hline & & Mean $32 \cdot 5$ & Total 95 \\
\hline
\end{tabular}


during rest. The alveolar air in several further cases of congenital heart disease with cyanosis has quite recently been observed by French, Pernbrey, and Ryffel. ${ }^{1}$ In every case the alveolar $\mathrm{CO}_{2}$ pressure was very low. A preliminary account by Beddard and Pembrey of the alveolar air in several other very interesting cases appeared recently.2

\section{Conchusions.}

1. During rest and at ordinary atmospheric pressure a normal or nearly normal alveolar $\mathrm{CO}_{2}$ pressure may be said to be maintained in the following diseases of the blood: Chlorosis, pernicious anæmia, chronic polycythæmia with cyanosis and enlarged spleen, and secondary anæmia due to severe hæmorrhage.

2. Except in the condition of congenital heart disease a normal or nearly normal alveolar $\mathrm{CO}_{2}$ pressure was found as a rule to be maintained during rest in all the diseases of the circulatory and respiratory systems investigated. This fact points to complete circulatory compensation during rest.

3. In a case of congenital heart disease the alveolar $\mathrm{CO}_{2}$ was maintained at a tension considerably lower than normal.

4. No constant parallelism could be traced between the partial pressure of $\mathrm{CO}_{2}$ in the alveolar air and either the amount of hæmoglobin present or the number of red blood corpuseles.

5. From the maintenance of the alveolar $\mathrm{CO}_{2}$ at a normal pressure in chlorosis and in other anæmic conditions, it must be inferred that a circulatory adaptation of increase in rate of blood flow gradually occurs, so that no want of oxygen results during rest. With a normal rate of circulation, and the oxygen-carrying power of the blood reduced to one-third of the normal or less, there would be symptoms of oxygen asphyxia.

At high altitudes, where the alveolar $\mathrm{CO}_{2}$ pressure is diminished, such an adaptation does not succeed, owing to the incomplete saturation of the arterial blood with oxygen, while in $\mathrm{CO}$ poisoning there is insufficient time for the adaptation to take place.

In conclusion, I desire to express my sincere thanks to Dr. J. S. Haldane for his valuable suggestions and for the loan of apparatus.

\section{REFERENCES.}

1. Haldane and Prinstley - Journ. Physiol., 1905, vol. xxxii. p. 225.

2. FitzGrald and Haldane Ibid., 1905, vol. xxxii. p. 486.

1 Journ. of Physiol., Cambridge and London, "Proc. Physiol. Soc.," 1909, vol. xxxix. p. ix.

${ }^{2}$ Brit. Med. Journ., London, 1908, vol. ii. p. 580. 